\title{
Nazi Collaborators in the Soviet Union during and after World War II
}

\author{
Boris Kovalev
}

\begin{abstract}
Based on documents from the Russian archives, which in the early 1990s became open to the researchers, the author gives an account of the problem of collaboration with Nazi Germany in the USSR during World War II. He discusses the role of special punitive detachments, formed from the local populations in the occupied territories, in assisting Nazis in their policy of terror and genocide. A brief history of the infamous 667th punitive battalion, "Shelon, " andsomeofitsmembers serves as an illustrative example. The author also explains why so many Nazi collaborators from the former Soviet Union managed to escape punishmentand settle in the Western countries, Canada and the United States in particular, and also traces the history of some of them.
\end{abstract}

\section{Precis}

En se basant sur des documents des archives russes devenus accessibles aux chercheurs au debut des annees 1990,1' auteur rend compte du probleme de la collaboration avec I'Allemagne nazie en URSS pendant la Seconde Guerre Mondiale. II analyse Ie role de detachements punitifs speciaux, qui etaientmis en place il partir $d$ 'elements issus des populations locales des territoires occupes, et qui avaient pour role d' assister I' occupant nazi dans sa politique de terreur et de genocide. Un bref historique du sinistre $667^{\text {ieme }} \mathrm{Ba}$ taillon Punitif" Shelon" et une description signazetique de certains de ses membres fournit ici un exemple

Dr. Boris Kovalev is Professor in the Department of Law, Novgorod State University named after Yaroslav Mudrii, Novgorod, Russia.

The full names of the alleged Nazi criminals mentioned in the article are in the Archives of the Administration of the National Security Service of the Russian Federation.

This article was translated from the Russian by Roza Kovalev.

Refuge, Vol. 17, No.2 (April 1998) illustratif. L' auteur explique aussi comment un si grand nombre d' anciens collaborateurs nazis de I' ex-Union Sovietique ont pu echapper illeur peine et s' installer sans €lre inquieUs dans plusieurs pays occidentaux, notamment Ie Canada et les Etats-Unis, et retrace l'historique de la trajectoire de certains d' entre eux.

\section{Introduction}

The problem of Nazi collaborators during and after World War II has been the subject of my research since my student days. But it was only in early 1991 that I could approach it professionally for the first time. Once many positive political changes took place in Russia, I received access to the Archives of the Administration of the National Security Service in Russia. This paper is based on the documents, which were obtained from these archives.

The nature of this work there was quite challenging. In some archives the documents from the World War II period are not indexed and those who work in the archives do not know their volume numbers and the information these documents contain. It is no exaggeration to say that after many years of silent storage in the archives of Russia, many of these documents were first touched byme.

After World War II,millions of people found themselves far from their original places of residence. The reasons for this situation were both attempts to save themselves from the atrocities of the military actions and to escape the punishmentfor crimes they had committed. Dozens of names of those who had been involved in the Nazi crimes during World War II are known to me from the materials stored in the civil, military, and KGB (Committee for State Security) archives. Many of those guilty of crimes managed to emigrate and settle in Canada and the United States under a false identity or by concealing their past. Thus, it is still too early to say with con- viction that the problem of Nazi crimes during World War II has been solved, since not all Nazi criminals have received appropriate punishment for their atrocities. This paper also mentions a number of Nazi criminals and collaborators from Russia whose lives have been investigated in detail.

\section{Special Detachments from the Local Population}

In the occupied countries ofEurope, the Nazis pressured local populations to cooperate with them. These collaborators were usually assigned to fulfil the most "dirty" jobs connected with the extermination of the population. In their attempts to subjugate the local populations, the Nazis created the socalled "bodies of new administration," that co-opted the services of those willing or coerced to collaborate with them.

The initiative for the creation of the local administration came from the military commandant's office, which badly needed the support of institutions of civil management. In the cities and towns these "bodies of new administration" were widely created. They constituted the executive and administrative units of the local self-government and incorporated the police, finances and taxes, as well as assistance to the families whose members went to work in Germany. The control of these bodies stretched beyond the interests of a given city or town and had a general regional scope.

In the rural areas, administrative functions were fulfilled by the so-called Golovy (Heads). In August 1941, the occupants made it clear that beside the definite administrative functions (tax collection, control and the surveillance of the local population for the anti-German spirit), the Heads were responsible for bringing all regulations of the German Administration to the attention of the local population and for the promotion of the ideas of "Great Germany and 
National Socialism." To control the occupied territory, German military forces began to create" services of order." According to the regulations, such services had to keep public order and maintain security among local population, provide assistance to the occupants in the execution of the criminal police missions SD (Sicherheitsdienst, or Security Service) aimed against any form of the anti-government activity.

\section{Special Detachments in the Territory of the Former Soviet Union}

The" services of order" were widely diffused throughout the territory of the former USSR (Soviet Union). In different occupied regions of the country, a variety of police divisions were established. The Nazis invested big hopes in the persons who had been persecuted by the Soviet administration. Apart from common criminals, there were many people who had suffered from collectivization and repressions in 1937-38. The functions of the police ranged from looking after order in the streets to fighting with subversive elements.

One of the main targets of the German administration was the complete passportization (identification) of the local population which was carried out by the Russian police. The Military commandant of the city of Staraia Russa stressed:

By the complete identification of and registration of the local population by issuing passports to each person, they will reveal the unwanted elements, this will also make it easier for the police to work with the population in terms of search of suspicious personspartisans and Soviet spies. $^{1}$

The heads of the police units were ordered to create a net of trustworthy people in the shortest time possible, and to use them for the identification of persons with hostile attitudes to the German occupants. They were encouraged to hire relatives and close friends for this job.

The policemen monitored the local population and were used by the Nazis to participate in the extermination and punitive operations. Usually, the police would prepare two different lists of population: one for the Jews and the other for politically unreliable persons. After the suspects were identified, the police would search them out and arrest them and they would be jailed after an investigation. For these purposes, a special investigation department was established. When the arrested persons were incarcerated, it was up to commandants and police to deal with themthey made decisions on the form of the punishment: whether to execute a suspect, to send him/her to the incarnation camp or to let him/her go free.

The city of Staraia Russa, for example, was at the front zone and Nazis decided "to solve the Jewish question" in the shortest time. Hence, during the autumn of 1941, the Jewish population was taken out of the city and exterminated. These actions were explained in the following way:

1. thewarwasunleashedattheJewish initiative;

2. Jews were the nation of parasites living at the expense others; and

3. having seized the power in Russia, Jews created the Soviet jail system for the people.

Thus, the conclusion thatfollowed was: "The end to Jews means the end to the war."

The persons who were collaborating with the occupants and working with the police were punished accordingly after the war, but many of them managed to escape punishment by hiding or concealing their identity.

One of the armed detachments which was active in the territory of the northwestern part of Russia was the 667th punitive battalion "Shelon," belonging to the 16th army of Wehnnacht under the management of the military intelligence service. The battalion was setup in February 1942, and it was formed from prisoners of war and the local population of the occupied districts of the Leningrad region. It consisted of six divisions and had 700 persons in service.

In 1942-43, this battalion destroyed more than forty residential areas and carried out multiple group and single executions. The main task for this force was "the final solution of the Jewish question." It was assumed that the justification for the extermination of the Jewish population would be explained by the following statement, "Stalin, communists and Jews are guilty of this war from which the Russian population is suffering so much."

Those Jewish people who remained alive by 1942, had to wearidentification signs, in some places these were yellow and white stars, in other places bands on the sleeves. The military authorities decided to issue a daily ration of 100 grams of bread a day per person in Jewish ghettos, and the most insignificant offence resulted in the denial of this bread ratio. In such places as Pskov, Dno, and Ostrov, all Jewish men, male teenagers and boys were exterminated. The battalion played a direct and key role in the annihilation of the Jewish population. The military anti-Semitism was a part of the state policy of fascist Germany. In these conditions, the participation of the Jewish people in military actions on Hitler's side was thought to be impossible, but history proved otherwise. A resident of the city of Krasnograd of the Charkov region, Grigori Moiseevich Gurevich, a sergeant of the Red Army, was taken prisoner by the Germans in 1941 in the vicinity of Leningrad. As a Jew, he could be shot on the spot, but he managed to conceal his background. He said that he was Ukrainian-Grigori Mikhailovich Gurvich and was, therefore, sent to a military prison. Gurevich tried to flee twice and twice he was caught. After the last attempt, the head of the prison gave him two options-to be executed or to become an executioner. Gurevich chose the second option, and the first task he was given by the Nazis was to execute his comrades in flight. When the Germans began to form punitive battalions, Gurevich became a soldier in one of them. He was a machine-gunner and he participated in punitive actions more than once, dealing with the local population allegedly in contact with the guerrillas. In 1943, he was wounded. The Red Army was advancing and soon Gurevich was taken prisoner by the Soviets, but during the interrogation, he

Refuge, Vol. 17, No.2 (April 1998) 
managed to hide his membership in the punitive battalion. He was conscripted to the acting Red Army with which he reached Berlin. He also received military rewards for his service.

After the war, he resided in Leningrad without attracting the attention of the KGB. It was the KGB, which searched for military criminals in the USSR. This continued smoothly up to 1973 , when Gurevich applied to emigrate to Israel. During a very painstaking verification of his documents the inconsistencies were revealed. This led to suspicions, and after a number of inquiries and cross examinations, it became clear that Gurevich, a person applying to move to Israel, and, Gurvich, a soldier of the Nazi punitive battalion, were one and the same person. The court sentenced him to the severest possible punishment, the death penalty.

\section{Former Nazi Criminals in North America}

In the autumn of 1943, the "Shelon" battalion was transferred to Denmark to defend the shore from the possible landing of the Allies there. Many former soldiers from the "Shelon" battalion were able to move to the United States and Canada and settle there. Information from the criminal investigation department of Russia made it possible to follow their route-from active Nazi collaborators, who were performing the dirtiest jobs, to the decent citizens who established themselves in the Western countries.

At the time when the Nazi troops were victorious, it was not difficult to pick up people from the occupied population who would co-operate with them for certain benefits, but at the end of1943 the situation changed drastically. The socalled "additional allied detachments" started to lose their ability to fight. Many collaborators who did taint themselves with blood started to flee and join the resistance forces. This tendency was apparent not only in Russia but in other countries as well, and in these situations, the Nazis undertook the policy of relocating the collabora-

Refuge, Vol. 17, No.2 (April 1998) tors from the east to the west and the other way round.

Thus, many Nazi collaborators from Russia found themselves in France, Denmark, and Norway as the result of the relocations. They had to fight the local population there and guard the shoreline from the landing of EnglishAmerican forces. The luckiest ones were those who had been sent to Scandinavia, since they did not participate in military actions up to the spring of 1945. They did not resist the approaching allied forces and were taken prisoners without a fight. After the war, the Soviet government requested the immediate release and forced return of all former soldiers of the punitive detachments to the USSR, so they could face punishmentthere, but the Allies, mainly British took their time. They knew that Stalin had ordered public hangings of anyone alleged to have collaborated with the Nazis. If they were not hanged they would be destined to serve long prison terms. Stalin's justice was not interested in the genuine facts. Very often, crimes of different weight were punished equally. In these conditions, the British officers had to choose between the immediate fulfilment of the requests of the Soviet side (according to the Yalta Agreement, all citizens of the USSR had to be returned to their "motherland") or to investigate each case separately.

All persons involved in military crimes did their best to escape deportation to the USSR. They tried to convince the Allied officers that they had been forced to put a German military uniform on and the reasons to do so were the following:

1. They wanted to save themselves from the inevitable death from starvation in the German concentration camps.

2. They intended to help the local population in some way.

3. They hated the Soviet regime which exterminated the best representatives of the Russian nation.

Some of them maintained that their participation in the war on the German side was a form of resistance to the totalitarian communist regime. And all of them without exception denied their participation in punitive actions against the civil population. It was impossible to verify their words. They were granted the opportunity to stay in the Western Europe.

After World War II, Europe lay in ruins. Its eastern part was under USSR control; in its western part, particularly in France and Italy, the communist parties were consolidating their positions. That was the main reason why former collaborators felt like moving as far as possible from places of the recent military actions. In such circumstances, Canada and the United States became the preferred countries for emigration and settlement.

According to the available information, all collaborators who managed to emigrate to Canada and the United States became law-abiding citizens. They were not known toqeate problems for the authorities of their new countries of residence. Thus, the Commander of the SS battalion, A. R. and major of the Wehrmacht who was awarded two "Iron Crosses" was residing in the city of Cleveland (USA) until the end of 1970s. His deputy, P. R. found home in the same place. According to the documents, A. R. was an "accomplished" sadist. He enjoyed the most cruel tortures of prisoners. He entertained himself by hanging prisoners by their genitals. His deputy was nicknamed "Sanitar" because he used to shoot prisoners on the ice of frozen lakes and rivers. He shot his victims and then dumped them under the ice. In this manner, he murdered all of the residents of the village of Borki. These former members of the punitive battalion were working on the railway road in the United States up to the 1970 s. $^{2}$

Some members of the same battalion suchasF. P.,and V. V., who also participated in the bloody murders, came to Canada and became residents there. According to the testimony of witnesses, in December of1942, they supervised the shooting of the peaceful population at the river Polist, which is in the northwest of Russia. One of the witnesses testified, "Among the bodies there was a wounded boy of 9-10 years, he was crying and sobbing from pain, 
two killers, [F. P. and V. V.], who were nicknamed Vasia and Skobar, approached the boy and gunned the boy."3 From the 1950s, bothF. P. and V. V. were residing in Toronto. F. P. resided in Mississauga and later he moved to Toronto. He became aneighbour ofV. V., his companion in the punitive actions.

Apart from these two, other alleged killers from the same battalion moved to the country of the Maple Leaf. These ineluded S. K., V. S., and V. L. The first one showed the most horrible cruelty towards the Jewish population. V. S. and V. L. eagerly followed orders and solved the "Jewish problem" in the city of Porchov completely. They were appointed to work at the Commandant's office. First of all, they started with cutting the bread ratio in the ghetto by half, that is to 50 grams of bread per person. This is how they explained their actions, "Russian people are starving and in this situation, Zydy [a diminutive Russian term for Jews] do not need food." The Jewish population of the ghetto faced starvation, and people were getting weaker and weaker, and many became too exhausted to go to work. V. S. and V. L. daily inspected the houses where the Jewish people lived and beat to death those who were still alive buttoo weak to move. According to the reports, which were found in the archives, those two murdered more than 20 Jewish persons. V. L. settled in Toronto. ${ }^{4}$

During the first months after the war, the government of the USSR created special bodies that were in charge of returning objects of art from the territory of Germany and its allies, that had been seized by Germany in Russia between 1941 and 1944. The relocation of the art objects to the Third Reich was monitored not only by Nazi Germany government authorities, but also by individual officers and soldiers who were often assisted by local persons.

In recent years, the interest of the public in the problems ofrecovery of the lost property, i.e. the recovery of the assets which were relocated in the years of Wodd War II, has increased.

The story of $\mathrm{V}$. P. reflects this issue and is worth discussing. He was the first city head of the ancient Russian city of $\mathrm{N}$ ovgorod during the German occupation. He was a professional historian and before the war he worked in the HistoricalMuseumofNovgorod. There was no time to evacuate all the exhibits from the museum; many were left in Novgorod whichwas occupied by the Nazis in August of 1941. V. P. participated directly in the transfer abroad of the most valuable objects of art. ${ }^{\mathrm{s}}$ Lost forever were the collections of ancient Russian Icons and French paintings of the 18th century. Among other lost paintings, we can mention the canvas of Peter Paul Rubens, "The Portrait of $\mathrm{V}$ espasian." These paintings belonged to the private collections of Russian noblemen who resided in this area before the October Revolution of 1917. They were seized during the Revolution and distributed among the museums. The museum of Novgorod ranked high in the collections of art before W orid War I!.

V. P . left Russia for Germany in 1943 and for some time any trace of him was lost. At the end of 1950s, he was seen in Italy and in the United States, and at the same time the paintings from the Novgorod museum appeared in the art market. In 1988, when Novgorod celebrated the millennium of the adoption of Christianity, St. Sophia Cathedral of Novgorod received a gift from an American collector, the icons that had been lost during the war. Art critics and historians assumed that these icons had been seized by $\mathrm{V}$. P. whose responsibility was to look after the storage of icons in Novgorod.

The cold war and the situation of mistrust between the East and the West helped many Nazi criminals to escape the punishment they deserved. After the death of Stalin, the international situation became more flexible. The new policies of Nikita Khrustchev allowed masses of the imprisoned to be set free and in this new situation the Soviet secret services abandoned the search for false criminals. The KGB created new structures, which enforced the search for Nazi war criminals, but it would be unjust and wrong to say that no work had been done before. The KGB had the files of all persons who were under suspicion. Their friends, relatives and colleagues were questioned; their correspondence was constantly checked and attempts were made to locate them.

At the end of the 1950s, mail from abroad began to come to the USSR. The authors were people who had been forcefully moved to work in Germany during Wodd War II and who decided after the war not to return to the USSR. Officers of the KGB were looking for any piece of information that could shed some light on the war criminals. We can assume that Soviet diplomats and other representatives of the USSR abroad were involved in the same work, i.e. to collect all possible information about the war criminals. The majority of the criminals had been located and at this point the work was stopped except in one instance. In the middle of the 1960s, a scandal was sparked in Germany because one of the former Nazi criminals had a high position in the Constitutional Court of the Federal Republic of Germany. As a result the former SS officer lost a prestigious position.

The materials on former Nazi collaborators who resided in Canada and the United States were prepared for a meeting between Leonid Brezhnev and Gerald Ford in the City of Yladivostokin 1974. The Soviet periodicals appeared to have numerous materials about the Nazi punitive actions, its victims and the perpetrators of these crimes. The number of witnesses was very large and U.S. authorities suggested that the witnesses should be allowed to travel to the United States to help in the investigation; but the Soviet authorities refused to cooperate. Many witnesses have now passed away.

\section{Conclusion}

Nazi crimes were committed more than 50 years ago but we have to remember that the decisions of the NurembergTribunal have not been annulled, and that crimes against humanity do not have time limits. More than fifty years have passed since the day when Wodd War II, the bloodiest war in the history of mankind, ended. The main culprits of the war, the German fascists were pun- 
ished. The leaders of the Third Reich were charged with crimes against humanity and received severe sentences, usually the death penalty. Also many of those who collaborated with the Nazis and executed the orders to exterminate both Germans and the representatives of other nations were also pUnished, but there were many who managed to escape justice and hide in the countries of the anti-Hitler coalition. I I

\section{Notes}

1. The Archives of the Administration of the National Security Service of the Russian Federation of the Novgorod Region. Archives Criminal Record: No. 1/6995, Vol. I, 164-65.

2. The Archives of the Administration of the National Security Service of the Russian Federation of the Leningrad Region. Archives Criminal Record: No. 19344A19143, Vol. 2.

The Archives of the Administration of the National Security Service of the Russian Federation of the Novgorod Region. Archives Criminal Record: No. 1/6995, Vol. 4.

3. The Archives of the Administration of the National Security Service of the Russian Federation of the Novgorod Region. Archives Criminal Record: No. 43689,34-35.

4. The Archives of the Administration of the National Security Service of the Russian Federation of the Pskov Region. Archives Criminal Record: No. C 14643, Vol. 3.

5. The Archives of the Administration of the National Security Service of the Russian Federation of the Novgorod Region. Archives Criminal Record: No. 2/4995, Vol. 1.

\section{Bibliography}

The Archives of the Administration of the National Security Service of the Russian Federation of the Novgorod Region. Archives Criminal Records: No. 19094 (Vol. 1,2,6),No. 1/6995 (Vol. 1),No.43689,No. 2/4995 (Vol. 1).

The Archives of the Administration of the National Security Service of the Russian Federation of the Leningrad Region and the City of St. Petersburg. Archives Criminal Record: No. 19344.

The Archives of the Administration of the National Security Service of the Russian Federation of the Pskov Region. Archives Criminal Records: No. C 16229, No. C 7014, No. C 14643, No. 2467. cl

Refuge, Vol. 17, No. 2 (April 1998)

\section{Back Issues of Refuge}

The following is a list of general and thematic issues of Refuge-Canada's periodical on refugees.

1. Environmental Refugees, Vol. 12, No. 1, June 1992.

2. Discussion of Immigration Bill C-86, Vol. 12, No. 2, July/(Aug.) 1992.

3. General Issue/Refugee Sponsorship, Vol. 12, No. 3, Sept. 1992.

4. Eastern European Refugees, Vol. 12, No. 4, Oct. 1992.

5. The Tragedy of Somalia, Vol. 12, No. 5, Nov./Dec. 1992.

6. The Review of Rejected Refugee Claims in Canada, Vol. 12, No. 6, Jan. 1993.

7. Russia and Central Eurasia, Vol. 12, No. 7, February 1993.

8. Africa Issue: Repatriation, Vol. 12, No. 8, March 1993.

9. General Issue/Globalization, Vol. 13, No. 1, April 1993.

10. Russia and Central Eurasia, Vol. 13, No. 2, May 1993.

11. Special Issue on Sri Lanka, Vol. 13, No. 3, June 1993.

12. Gender Issues and Refugee Law, Vol. 13, No. 4, July/Aug. 1993.

13. Southeast Asian Refugees, Vol. 13, No. 5, Sept. 1993.

14. Mozambican Refugees, Vol. 13, No. 6, October 1993.

15. Russia and Central Eurasia, Vol. 13, No. 7, Nov./Dec. 1993.

16. General Issue/Sudan, Vol. 13, No. 8, January 1994.

17. Integration of Refugees-The Canadian Experience, Vol. 13, No. 9, Feb. 1994.

18. Refugees and Peace in Central America, Vol. 13, No. 10, March 1994.

19. Horn of Africa, Vol. 14, No. 1, April 1994.

20. The Russian Federation, Vol. 14, No. 2, May 1994.

21. The Former Yugoslavia, Vol. 14, No. 3, June/July 1994.

22. General Issue/IRB and Rebuilding Trust/Tamil Immigrants in Canada, Vol. 14, No. 4, Aug./Sept. 1994.

23. Rwandan Crisis, Vol. 14, No. 5, October 1994.

24. Refugee Resettlement in Israel, Vol. 14, No. 6, Nov. 1994.

25. Refugee Women-Part 1: Issues, Vol. 14, No. 7, Dec. 1994.

26. Refugee Women-Part 2: Case Studies, Vol. 14, No. 8, Jan. 1995.

27. The Safe Third Country Concept, Vol. 14, No. 9, February 1995.

28. Special Issue on Chechnya, Vol. 14, No. 10, March 1995.

29. Reformulation of International Refugee Law, Vol. 15, No. 1, 1996.

30. Environment, Development and Refugees, Vol. 15, No. 2, 1996.

31. International Intervention in Refugee Crises, Vol. 15, No. 3, 1996.

32. Early Warning on Humanitarian Crises, Vol. 15, No. 4, 1996.

33. Child Refugees, Vol. 15, No. 5, 1996.

34. Global Settlement Services, Vol. 15, No. 6, 1997.

35. Early Warning and Early Response, Vol. 16, No. 1, May 1997.

36. Uprooting and Consequences, Vol. 16, No. 2, June 1997.

37. Development-induced Displacement, Vol. 16, No. 3, August 1997.

38. Refugee and Immigrant Women: An International Perspective, Vol. 16, No. 4, October 1997.

39. Working with Refugees and Internally Displaced Persons, Vol. 16, No. 5 , November 1997.

40. Conflict, Population Displacement, and Conflict Resolution, Vol. 16, No. 6, December 1997.

41. Refugee and Immigrant Women: An International Perspective, Part II, Vol. 17, No. 1, February 1998.

Single copy: Vol 12, 13 \& 14-\$6.50; Vol 15, 16, 17-\$10. 10 percent discount on 3-9 issues (copies); 20 percent discount on 10 issues (copies) or more. Special discounts are available for students and exclusively volunteer-run NGOs. P. O. accepted.

Please send your orders to:

Centre for Refugee Studies, York University

Suite 333, York Lanes, 4700 Keele Street

Toronto, Ontario, Canada M3J 1 P3

Fax: (416)736-5837.Email: refuge@yorku.ca・mswinder@yorku.ca 
Refuge

Centre for Refugee Studies

Suite 322, York Lanes York University

4700 Keele Street, Toronto

Ontario, Canada M3J 1P3

Phone: (416) 736-5663 Fax:

(416) 736-5837

Email: refuge@yorku.ca

\section{CALL FOR PAPERS}

\section{Not Just Numbers; Legislative Review: Implications for Refugee Policy}

\section{Guest Editor Prof. Michael Lanphier}

The issue presents an account of the Legislative Review Not Just Numbers. As the first systematic externally commissioned review of refugee and immigration policy in more than two decades, the issue examines background to the review process, the report, with emphasis on refugee policy and types of response from the actively interested segments of the Canadian public. An important feature is the role and effectiveness of public inquiry in the form of a Legislative Review in the revision of refugee policy from the standpoint of those who consider themselves stakeholders.

Possible articles:

- Refugee policy implementation in the 1990s: major gaps and problems.

- Refugee policy and immigration policy: two aspects of the same thing?

- Legislative Review: steps to preparing a public report.

- NGOs view the report: responses and problems identified ( $3-4$ brief accounts).

- Voices of former refugees (brief accounts).

- Views from abroad (reactions from other countries)

- Prospects of reform: government and Canadian society.

Contributions with abstracts are invited. They must be received not later than October 15, 1998. Papers should be typed, double-spaced, and referenced in proper academic form. They should not exceed 16 pages or about 4000 words. Short papers of about 900 words are also welcome. Word-processed submissions may be sent on disc or by e-mail.

On accepte aussi des articles en français. Le style doit conformer aux normes exigés pour les articles rédigés en anglais.

Deadline: October 15, 1998.

For further details, please contact:

Prof. Michael Lanphier, Editor, Refuge (Canada's Periodical on Refugees)

Centre for Refugee Studies, York University, Suite 322, York Lanes

4700 Keele Street, Toronto, Ontario, Canada M3J 1P3

Fax: (416) 736-5837 - Tel.: (416) 736-2100 ext. 20563/77011

Email: lanphier@yorku.ca・refuge@yorku.ca 